\begin{tabular}{|c|c|c|c|c|}
\hline $\begin{array}{c}\text { 118SHARE: SOCIAL WORK } \\
\text { JURNAL }\end{array}$ & VOLUME: 7 & NOMOR: 1 & HALAMAN: $1-129$ & $\begin{array}{l}\text { ISSN:2339 -0042 (p) } \\
\text { ISSN: 2528-1577 }(e)\end{array}$ \\
\hline
\end{tabular}

\title{
MASALAH SOSIAL DAN WIRAUSAHA SOSIAL
}

\author{
Oleh : \\ Budi Muhammad Taftazani ${ }^{1}$ \\ 1. Pusat Studi Kewirausahaan Sosial, CSR dan Pengembangan Masyarakat
}

Email:

(budimtunpad@gmail.com)

\begin{abstract}
Abstrak
Memahami masalah sosial sangat penting bagi mereka yang bergerak di bidang social entrepreneurs. Dengan memahami keluasan serta kedalaman masalah, maka kita akan terbantu menemukan peluang-peluang untuk aksi penanganan baik yang sifatnya pencegahan, penyelesaian, atau pengembangan. Penyebab masalah sosial sangatlah kompleks merentang dari dimensi yang terkait dengan pola tingkah laku, pola interaksi, perubahan dan konflik nilai, sampai yang diakibatkan oleh situasi ketidakadilan, pengabaian terhadap hak-hak asasi manusia, serta kerusakan ekologis yang parah.

Ditengah berbagai masalah sosial yang semakin kompleks baik dari penyebab maupun akibatnya, diharapakan muncul para wirausahawan sosial yang mampu menyumbangkan ide dan aksi untuk masalah-masalah yang selama ini dianggap tidak terpecahkan. Dibutuhkan rumusan-rumusan model kreatif dalam upaya pemecahan masalah sosial yang sebelumnya hanya didekati dengan cara-cara konvensional yang dicirikan dengan penerapan model-model kuratif, orientasi proyek jangka pendek, pengawasan implementsi yang lemah sehingga penuh ketidakkonsistenan antara tatanan ide dengan implementasi, dan tidak mampu memunculkan kesadaran kolektif masyarakat bahwa mereka adalah aktor utama perubahan. Sering pula terjadi pihak-pihak yang memiliki otoritas baru melakukan upaya pencegahan atau penanganan masalah setelah terjadi kerusakan yang signifikan.

Bagi para wirausahawan sosial, keadaan seperti demikian sebaiknya dilihat sebagai peluang untuk menciptakan model-model jitu diluar pendekatan biasa yang tidak menyelesaikan masalah atau bahkan hanya seolah-olah menyelesaiikan masalah. Saat ini banyak masalah sosial di Indonesia yang perlu menjadi perhatian baik itu yang bersumber dari disfungsi sosial individu, keluarga, atau disfungsi kelembagaan dan organisasi termasuk lembaga-lembaga pelayanan sosial dan publik.
\end{abstract}

Kata kunci: Masalah Sosial, Kewirausahaan Sosial, Wirausaha Sosial 


\section{Pendahuluan: Masalah Sosial}

Masalah sosial merupakan fenomena yang selalu ada pada setiap masyarakat di belahan bumi manapun. Selama masyarakat terus mengalami proses perubahan, maka masalah sosial akan terus muncul tanpa bisa dihindari serta sekaligus akan terus mempengaruhi dimensi kehidupan setiap orang. Korupsi, kenakalan remaja, disorganisasi keluarga, pendapatan yang rendah, drug abuse, kriminalitas, kekerasan dan sebagainya adalah masalah-masalah yang menunjukan banyak orang yang hidupnya tidak nyaman dan terganggu.

Masalah sosial ini penting dipelajari terutama oleh mereka yang secara langsung berhubungan dengan aktivitas-aktivitas sosial, pengambil kebijakan serta yang mengkaji secara langsung gejala ini. Dalam kajian ilmu sosial, ada kesulitan khususnya dalam melakukan generalisasi dari masalah sosial hinggga menghasilkan sebuah definisi. Hal ini dikarenakan banyaknya aspek serta dimensi dari masalah sosial serta adanya relativitas persepsi masyarakat mengenai masalah ini.

Satu kondisi sosial di sebuah masyarakat bisa disebut masalah sosial sementara di masyarakat lainnya tidak dianggap masalah sosial. Begitu juga dengan dimensi persepsi masyarakat yang berubah dari waktu ke waktu mempengaruhi bentuk masalah sosial sehingga satu fenomena sosial yang dianggap masalah pada masa lalu saat ini tidak lagi dianggap sebagai masalah sosial dan begitu pula sebaliknya. Perubahan masyarakat yang terus terjadi mempengaruhi munculnya masalahmasalah sosial baru, yang di masa lalu belum terjadi. Masalah sosial sangatlah berhubungan dengan persepsi serta nilai-nilai yang berlaku di sebuah masyarakat. Dengan demikian untuk mempelajari masalah sosial perlu disadari adanya kompleksitas dari bidang yang akan dipelajari. Banyaknya aspek dan dimensi dalam melakukan studi ini berimplikasi pada kearifan mengindentifikasi dan mengkaji masalah serta menentukan pendekatan dan strategi pemecahan masalah secara komprehensif.
Meski mengalami kesulitan membuat generalisasi untuk definisi maslaah sosial, beberapa rumusan telah dicoba dibuat meski antara satu dengan yang lainnya memiliki tekanan pada aspek yang berbeda. Namun demikian beberapa rumusan ini diharapkan dapat mendekati prinsip yang lebih objektif dan universal. Parrilo (2002:4) merumuskan empat elemen penting yang bisa menjadi pertimbangan suatu situasi dianggap sebagai masalah sosial, yaitu :

1. Dapat menimbulkan berbagai kerugian baik terhadap keadaan fisik atau mental baik pada individu atau pun pada masyarakat.

2. Merupakan pelanggaran terhadap satu atau beberapa nilai atau standar yang dimiliki oleh sebagaian besar masyarakat atau mereka yang memiliki kekuatan pengaruh di masyarakat.

3. Keadaan yang terus menerus terjadi

4. Memunculkan kebutuhan untuk dipecahkan berdasarkan evaluasi dari berbagai kelompok di masyarkat.

Sedangakn Raab dan Selznick (1964, dalam Soetomo), menyatakan bahwa tidak semua masalah dalam kehidupan manusia merupakan masalah sosial. Masalah sosial pada dasarnya adalah masalah yang terjadi dalam hubungan antar warga masyarakat. Hal ini menyangkut aturan dalam hubungan bersama baik formal maupun informal. Raab dan Selznick menyebutkan masalah sosial bisa terjadi bila memenuhi dua kriteria sebagai berikut,

1. Adanya hubungan antar warga masyarakat yang menghambat pencapaian tujuan penting dari sebagian besar warga masyarakat.

2. Organisasi sosial menghadapi ancaman serius oleh ketidakmampuan mengatur hubungan antar warga.

Ada juga definisi yang melihat masalah sosial sebagai keadaan yang dipersepsikan relatif oleh masyarakat yang berbeda, yaitu yang dikemukakan oleh Weinberg (1981), bahwa masalah sosial adalah situasi yang dinyatakan sebagai keadaan yang bertentangan dengan nilai-nilai yang dianut oleh sejumlah orang yang cukup signifikan, 
dan mereka memiliki kesepakatan dibutuhkannya tindakan untuk merubah keadaan tersebut. Dari definisi tersebut dapat dkatakan bahwa sebuah kondisi sosial disebut masalah sosial jika orang atau sekelompok orang yang memiliki pengaruh mnganggap situasi tersebut sebagia masalah. Yang dimaksud pihak berpengaruh tersebut yaitu bisa pihak yang memliki otoitas kekuasaan seperti pemerintah atau otoritas kemasyarakatan seperti tokoh masyarakat, atau otoritas keilmuan seperti para ilmuwan atau para ahli.

Dari definisi serta ciri-ciri mengenai masalah sosial, ada hal penting yang harus dicermati, yaitu bahwa masalah sosial adalah sebuah kondisi sosial yang rusak, buruk, dan tidak menyenangkan sehingga dari keadaan tersebut diperlukan adanya upaya untuk memperbaiki keadaan tersebut.

\section{Masalah Sosial Akibat Perubahan Sosial}

Masyarakat setiap saat mengalami perubahan baik itu yang direncanakan atau pun yang tidak direncanakan. Perubahan sosial terjadi ketika ada perubahan pada struktur sosial yaitu pola-pola tingkah laku dan interaksi masyarakat, perubahan pada dimensi status dan peranan, perubahan institusi, serta perubahan nilai-nilai di masyarakat. Setiap perubahan pada satu dimensi, mengakibatkan perlunya penyesuaian dari dimensi yang lainnya. Jika penyesuaian tidak terjadi, maka dimungkinkan muncul masalah sosial akibat dari ketidaksesuaian tersebut. Misalnya saat ini teknologi informasi mampu melintasi berbagai ruang budaya yang berbeda. Satu sisi ada pengaruh positif akibat bertukarnya informasi tersebut seperti berkembangnya ilmu pengetahuan dan teknologi, munculnya kesadaran mengenai interdependesi dalam kesatuan global community, dan sebagainya. Namun di sisi lain pengaruh buruk juga terjadi akibat pergesekan nilai budaya yang berbeda dan bertolak belakang.

Pada wilayah sosial yang lebih kecil misalnya pada keluarga yang baru terbentuk, tahap dan perkembangan di dalamnya membutuhkan pola perilaku, peranan, dan interaksi yang sesuai dengan fungsi-fungsi keluarga yang seharusnya. Bagaimana seorang perempuan yang tadinya hidup sendiri harus berperan sebagai seorang istri bagi pasangan hidupnya dan ibu bagi anak-anaknya. Begitu pula seorang pria yang semula memiliki pola hidup sendiri, maka setelah menikah harus berbagi tanggung jawab bersama pasangan hidupnya sebagai suami dan ayah bagi anakanaknya. Jika adaptasi dari perubahan tersebut tidak terjadi maka bisa memunculkan masalah dalam keluarga tersebut misalnya ketidakmampuan suami yang harus mencari nafkah sekaligus berperan sebagai kepala keluarga yang memimpin istri dan anaknya, atau interaksi yang tidak dibangun dengan pola komunikasi yang tepat antara anggota keluarga, tidak memiliki kemampuan dalam proses pembimbingan anak, bisa menyebabkan konflik-konflik serta ketidakharominsan keluarga sehingga bisa berakhir dengan perceraian, kekerasan, atau ketidaklayakan pengasuhan anak.

\section{Masalah Sosial dan Disfungsi Sosial}

Setiap manusia menjalankan fungsifungsi tertentu untuk menjaga kelangsungan hidupnya. Manusia akan berfungsi dengan baik jika ia dapat memenuhi kebutuhankebutuhan hidup serta puas dengan keadaan diri, dapat menjalankan peran-peran dalam kehidupannya dengan baik serta dapat melakukan interaksi positif dengan manusia lainnya. Jika seseorang tidak bisa menjalankan fungsi-fungsi tersebut maka ia mengalami disungsi sosial. Profesional yang bekerja membantu mengembalikan keberfungsian sosial orang adalah pekerjaan sosial. Mereka bekerja dengan individu, kelompok, keluaraga, masyarakat atau organisasi dengan basis pengetahuan serta metode yang dimilikinya.

Orang dengan fungsionalitas sosial ditunjukkan dengan kemampuannya menjalankan tugas-tugas kehidupan baik itu kehidupan pribadi maupun kehidupan dengan 
lingkungan masyarakatnya. Tugas-tugas tersebut mencakup memenuhi kebutuhan dasar (makanan, tempat tinggal, keselamatan, pemeliharaan kesehatan dan perlindungan), kebutuhan personal (pedidikan, rekreasi, nilai, estetika, spiritual, dan berprestasi), kebutuhan emosional (perasaan dimiliki dan memiliki, dukungan timbal balik, kebersamaan), serta memiliki konsep diri yang positif (kepercayaan diri, harga diri, serta identitas diri), (Barker,1987:152)

Sedangkan G. Thackeray dan Skidmore mengemukakan tiga aspek fungsionalitas sosial yaitu, individu merasa berharga dan puas dengan keadaan diri, puas dengan peranperannya dalam hidup, serta puas dalam interaksinya dengan orang lain. Jika terjadi ketidakpuasan dalam aspek-aspek itu, maka individu tersebut berada dalam keadaan disfungsi sosial.

Menurut perspektif pekerjaan sosial, ada dua bentuk keadaan berkaitan dengan fungsioalitas sosial. Pertama, adalah keadaan berfungsi sosial atau adaptive social functioning. Ini ditunjukan dengan kemampuan orang, organisasi, atau lembagalembaga menggunakan sumber-sumber personal, interpersonal, serta sumber-sumber kelembagaan lain untuk memecahkan masalah atau memenuhi kebutuhannya. Kemudian sumber-sumber tersebut secara relatif tersedia dan dapat diakses (DuBois\&Miley, 2005:14). Misalnya, seorang individu dikatakan berfungsi sosial jika ia berhasil menyesuaikan diri atau bisa keluar dengan baik dari situasi tekanan dan transisi pada tahap kehidupan seperti perkawinan atau perceraian, pemeliharaan anak, ditinggal oleh orang yang dicintai, kena PHK, atau menjalani masa pensiun. Saat masalah tersebut muncul mereka dapat mengatasi tekanan akibat masalah tersebut, beradaptasi terhadap perubahan, dan melakukan penyesuaian dengan lingkunagn serta situasi baru.

Bentuk kedua berkaitan dengan fungsionalitas sosial ini adalah disfungsi sosial atau maladaptive social functioning . Hal ini terjadi jika individu, kelompok, organisasi atau masyarakat tidak bisa keluar dari masalah yang dihadapi atau malah keadaan menjadi memburuk karena kemampuan mengatasi masalah tidak dimiliki atau mereka tidak memiliki inisiatif melakukan prubahan. Bisa saja situasinya orang yang bermaslah menyadari bahwa mereka menghadapi masalah yang berat sehingga menganggap diri mereka tidak berdaya. Misalnya anggota sebuah keluarga yang memiliki masalah komunikasi serius, atau individu yang mengalami depresi berat, kesendirian atau sebuah industri yang terancam produktivitasnya karena pegawainya mengalami stress dalam level yang tinggi

Masalah sosial dapat menyebabkan munculnya disfungsi sosial dan begitu pula sebaliknya, keadaan disfungsi sosial mempengaruhi munculnya masalah sosial. Misalnya anak yang terlantar dan terbuang karena fungsi-fungsi sosial dalam keluaga tidak berjalan, maka anak tersebut akan mengalami kesulitan dalam menjalankan tugas-tugas kehidupannya secara mandiri. Karena kebutuhan emosional dan personalnya tidak terpenuhi ia cendrung memiliki konsep diri yang buruk (hal sama dapat terjadi pada anak yang mendapatkan perlakuan kekerasan dalam keluarga). Jika tidak ada penanganan dengan segera, maka anak tersebut berpotensi untuk bertingkah laku menyimpang (deviant behavior). Dengan demikian keadaan disfungsi sosial dapat menyebabkan munculnya masalah sosial.

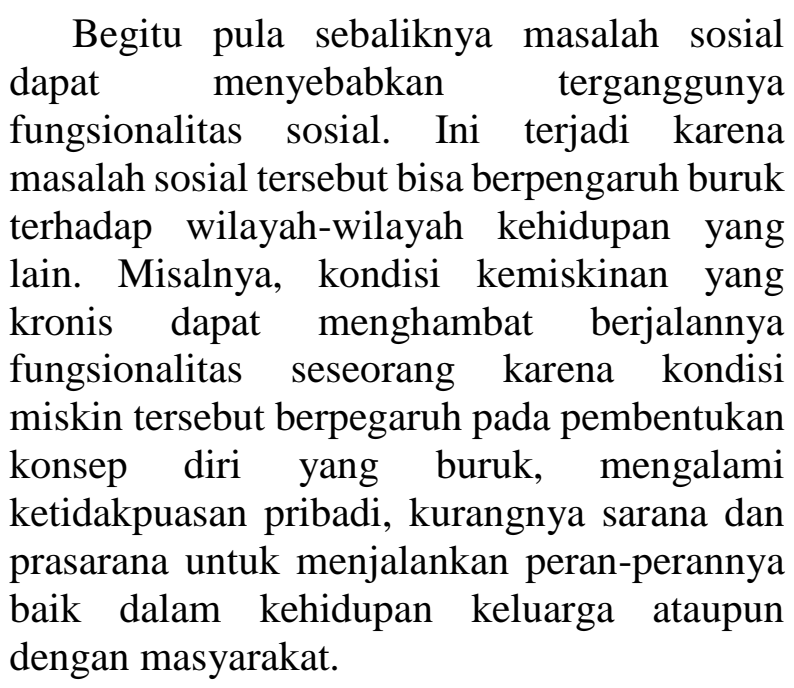

$\begin{array}{cl}\text { Begitu } & \text { pula sebaliknya masalah sosial } \\ \text { dapat } & \text { menyebabkan } \\ \text { terganggunya }\end{array}$ fungsionalitas sosial. Ini terjadi karena masalah sosial tersebut bisa berpengaruh buruk terhadap wilayah-wilayah kehidupan yang lain. Misalnya, kondisi kemiskinan yang kronis dapat menghambat berjalannya fungsionalitas seseorang karena kondisi miskin tersebut berpegaruh pada pembentukan konsep diri yang buruk, mengalami ketidakpuasan pribadi, kurangnya sarana dan prasarana untuk menjalankan peran-perannya dengan masyarakat. 


\section{Mengidentifikasi Sumber Masalah}

Untuk mencari model penyelesaian masalah social kita mesti mengetahui sumber penyebab masalah tersebut. Minimal ada dua pendekatan untuk memandang sumber maslalah sosial. Pertama, ada masalah yang dianggap bersumber dari individu (personal blame), Kedua, ada masalah yang dianggap bersumber dari sistem sosial (environmental blame). Individu dikatakan sebagai sumber masalah ketiika tingkah lakunya dianggap bertentangan dengan nilai atau standar sosial yang berlaku di masyarakat atau individu tersebut bermaslah karena ia memiliki kondisi mental yang buruk yang kemudian tingkah lakunya berpengaruh negatif pada orang lain. Misalnya seseorang karena kemampuan pengendalian emosi yang lemah saat berinteraksi dengan orang disekitarnya sehingga melakukan tindakan kekerasan. Dengan demikian ada gangguan interaksi antara dia dengan orang lain. Contoh lain terjadinya kemiskinan karena disebabkan rendahnya motivasi serta aktualisasi diri individu-individu miskin atau adanya angka putus sekolah yang tinggi karena kurangnya motivasi belajar serta ketiadaan orientasi masa depan.

Begitu pula denga gejala penyimpangan sosial (social deviant) yang diartikan dengan menyimpangnya perilaku individu dari nilainilai atau norma-norma yang berlaku di sebuah masyarkat. Pada saat penyimpangan individu ini terjadi, maka nilai-nilai yang berlaku yang bertujuan untuk menciptakan keseimbangan sosial dan menjaga integrasi sosial menjadi terganggu.

Sedangkan masalah sosial yang dianggap bersumber dari sistem sosial (environmental blame), terjadi jika lembaga-lembaga dan organisasi tidak berfungsi sebagaimana mestinya sehingga berpengaruh buruk pada sendi-sendi kehidupan masyarakat. Misalnya saja masalah korupsi di Indonesia yang sudah begitu meluas serta berlangsung lama dapat menyebabkan masalah lain seperti kemiskinan karena sumber-sumber kehidupan yang seharusnya dapat diakses secara luas menjadi hilang. Jika ada ganguan pada lembaga penegakan hukum dalam proses pemberantasan korupsi sehingga masalah terebut tidak bisa dihilangkan, maka dapat dikatakan bahwa sumber masalah berasal dari level sistem. Meski tentunya individu yang melakukan korupsi bisa dikatakan pula sebagai sumber masalahnya, namun bila korupsi terjadi dalam kualitas serta kuantitas yang besar di masyarakat, maka harus ada kontrol yang kuat dari sistem sosial, dalam hal ini adalah sistem penegakan hukum.

Bila personal blame menganggap bahwa sumber korupsi berasal dari mental atau perilaku buruk individu, maka environmental blame memandang bahwa sistem sosial harus memiliki fungsi memfasilitasi kehidupan warga agar fungsi-fungsi kehidupan masyarakat dapat berjalan. Jika kita menggunakan pedekatan komprehensif dari contoh kasus ini dapat dilihat bagaimana keterkaitan antara perilaku individu (yang melakukan korupsi) dengan sistem (yang seharusnya mengendalikan perilaku sekaligus melindungi setiap individu dari warga masyarakat).

Masalah lain yang bersumber dari sistem ini misalnya pada bencana alam yang sering terjadi di negeri ini yang disebabkan hilangnya keseimbangan ekosistem seperti banjir atau tanah longsor. Deforestasi, bangunan yang didirikan di daerah resapan air, serta banyaknya bangunan di hulu-hulu sungai utama di kota-kota besar adalah akibat adanya kesalahan tata ruang dan tata kota serta tidak ditegakannya hukum bagi mereka yang melanggar aturan tata ruang tersebut. Banyak masalah turunan yang berhubungan dengan bencana alam ini seperti jatuhnya korban jiwa, masalah kesehatan fisik dan mental, munculnya kemiskinan baru, dan sebagainya. Contoh lain yang menganggap sumber masalah berasal dari level sistim adalah kelemahan melakukan upaya preventif dan estimasi akan kemungkinan munculnya masalah oleh lembaga-lembaga yang memiliki otoritas karena kenyataannya seringkali 
penanganan masalah baru dilakukan setelah terjadi kerusakan yang dianggap signifikan.

Kadangkala dalam mengindentifikasi sumber masalah apakah dari individu atau sistem, memunculkan pemahaman saling mempengaruhi dilihat dari akibatnya. Misalnya masalah yang bersumber dari sistem dapat menyebabkan tingkat frustasi tertentu pada level individu. Tingkat frustasi yang tinggi dapat menyebabkan tingkah laku menarik diri (withdrawl) sehingga individu menjadi pasif dan tidak mau bertindak keluar dari masalahnya. Keadaan individu yang demikian bisa terus berlangsung meski sistem sosial awal yang menyebabkan dia frustasi sudah berubah dan membaik.

\section{Menterjemahkan Masalah Menjadi Kebutuhan}

Kita sudah mengetahui dua pendekatan dalam mengindetifikasi sumber masalah sehingga bisa dilihat apakah sumber masalah berasal dari individu atau level sistem atau bahkan mungkin untuk kepentingan penyelesaian masalah yang komprehensif kita menggunakan dua pendekatan tersebut pada saat yang sama, maka yang dilakukan kemudian adalah menterjemahkan masalah tersebut menjadi kebutuhan. Mengubah masalah menjadi kebutuhan ini penting dilakukan karena selanjutnya kita akan segera mengetahui sumber-sumber pemecahan masalah yang bisa dimobilisasi atau digerakan.

Untuk melakukan hal tersebut kita perlu mengetahui terlebih dahulu beberapa kemungkinan penyebab munculnya masalah sosial atau difungsi sosial baik pada level individu, kelompok, keluarga, masyarakat dan organisasi, yaitu sebagai berikut :

1. Tidak dimiilikinya kapasitas untuk memecahkan masalah (misalnya orang tua yang tidak memiliki keterampilan membimbing anak dengan baik)

2. Tidak adanya akses pada sistem sumber pemecahan masalah ( seperti pengguna narkoba yang ingin melepas ketergantungannya atau anak korban kekerasan tidak tahu kemana harus mencari pertolongan) atau akses tersebut mengalami gangguan

3. Adanya gangguan di dalam sistem sumber pemecahan masalah sehingga sistem tersebut tidak berjalan sebagaimanan mestinya (misalnya adanya praktik mafia peradilan atau penanganan suatu masalah di sebuah lembaga pelayanan sosial oleh orang yang tidak kompeten)

4. Tidak adanya kebijakan sosial yang memadai atau kemungkinan lain kebijakan tersebut tidak berpihak pada masyarakat yang lebih luas

5. Tidak tersedianya sama sekali sistemsistem pelayanan sosial yang langsung dapat memberikan bantuan

6. Terjadinya anomali atau mekanisme kontrol sosial di masyarakat tidak berfungsi, atau tidak ada sama sekali.

Dari kemungkinan keenam penyebab masalah tersebut kita dapat mengetahui apa yang harus dikembangkan atau diperbaiki sehingga muncul kebutuhan-kebutuhan akan pelayanan. Misalnya jika ada orang tua yang bermasalah dengan pembimbingan anak sehingga kerap terjadi pertengkaran atau bahkan tindakan-tindakan kekerasan, maka kebutuhan orang tua tersebut adalah penguasaan keterampilan pembimbingan anak dan kemungkinan lain kebutuhan untuk bisa melakukan self coping pada situasi-situasi distress. Pada kasus yang lingkupnya makro, bentuk-bentuk tindakan yang dibutuhkan mencakup mengembangkan atau merubah kebijakan-kebijakan sosial, melakukan kontol sosial, perencanaan sosial, advokasi, kampanye, pengembangan masyarakat, aksi sosial, dan sebagainya sesuai isu yang berkembang.

Dalam sistem pelayanan sosial seringkali diperlukan pendekatan multi disiplin sehingga treatmen yang dilakukan berdasarkan pada kebutuhan manusia yang utuh dan holistik. Untuk mengembangkan bentuk-bentuk pelayanan, seringkali diperlukan pelibatan berbagai profesi untuk mengefektifkan pencapaian kebutuhan-kebutuhan pelayanan. 
Hal ini berbeda dengan pendekatan pelayanan tradisional yang melihat penyebab dan penyelesaian masalah hanya dari satu perspektif.

Para profesional yang terlibat seperti pekerjaan sosial, psikolog, dokter, adalah orang-orang yang memiliki keahlian sesuai dengan pendidikan formal yang telah mereka tempuh. Sesuai kompetensinya mereka terlibat dalam pekerjaan-pekerjaan pelayanan sosial seperti di pelayanan rehabilitasi pengguna narkoba, program-program pencegahan dan perawatan penderita HIV/AIDS, pelayanan di rumah sakit, pelayaan kesehatan mental (mental health care), pengembangan masyarakat (community development), atau pemberian bantuan pada korban bencana alam, dan sebagainya. Sedangkan pada kebutuhan lain misalnya untuk aksi-aksi sosial yang lebih melibatkan isu publik seperti advokasi, perencanaan sosial, mempengaruhi kebijakan sosial, pengorganisasian dan pengembangan masyarakat, maka profesi yang dibutuhkan ternasuk ahli hukum, pekerjaan sosial, pendidik, dan sebagainya.
Menterjemahkan masalah menjadi kebutuhan berarti pula mengidentifikasi berbagai sumber daya yang dibutuhkan termasuk sumber daya manusia yang akan dilibatkan dalam kegiatan pelayanan.

\section{Model Penanganan Masalah}

Masalah sosial dapat dipicu oleh satu atau beberapa penyebab yang dianggap menganggu. Jika orang tidak memiliki kemampuan untuk mengatasi tekanan akibat gangguan ini, atau tidak dapat beradaptasi terhadap perubahan yang tiba-tiba, maka ia akan mengalami masalah. Jika orang tidak bisa keluar dari masalahnya, maka kondisi ini dapat memunculkan efek dalam bentuk masalah berikutnya. Hubungan ini terlihat dalam contoh mengapa orang terlibat dalam penggunaan obat-obat terlarang termasuk alkohol (alcohol and other drug abuse) dan apa efek buruk (masalah baru yang muncul) akibat penggunaan obat-obat tersebut. Efek tersebut berupa gangguan pada dimensidimensi kehidupan seseorang baik yang sifatnya fisik, psikis, sosial, atau spiritual.

Tabel Model Model Penanganan Masalah

\begin{tabular}{|c|c|c|c|}
\hline \multicolumn{2}{|c|}{ Penyebab } & Masalah & Efek \\
\hline Eksternal & Internal & & \\
\hline $\begin{array}{l}\text { - Adanya tugas- } \\
\text { tugas kehidupan } \\
\text { yang berat } \\
\text { - Konflik } \\
\text { interpesonal } \\
\text { - Pengaruh peer } \\
\text { group (pada } \\
\text { remaja) } \\
\text { - Kemudahan akses } \\
\text { terhadap substansi } \\
\text { ilegal }\end{array}$ & \begin{tabular}{lr}
\multicolumn{2}{l}{ kemampuan } \\
problem solving \\
untuk memecahkan \\
masalah dalam \\
tugas-tugas \\
kehidupan rendah \\
serta self coping \\
yang rendah, \\
memunculkan \\
tekanan/distress/ \\
kecemasan/ frustasi
\end{tabular} & $\begin{array}{l}\text { Penggunaan substansi } \\
\text { terlarang }\end{array}$ & $\begin{array}{l}\text { - Kerusakan fisologis-fisik } \\
\text { (organ-organ tubuh), } \\
\text { Penyebaran HIV } \\
\text { - Psikhis : emosional } \\
\text { self centered, low self } \\
\text { esteem, gangguan fungsi } \\
\text { kognitif, dll } \\
\text { - Sosial : self centered, } \\
\text { kekerasan,tidak } \\
\text { peduli,menghindari } \\
\text { tanggung jawab, dll } \\
\text { - Spiritual : hilangnya } \\
\text { sistem kepercayaan, } \\
\text { kehidupan dipandang } \\
\text { tidak berarti }\end{array}$ \\
\hline
\end{tabular}


Dari ilustrasi di atas dapat diliihat bahwa satu masalah dalam hal ini AODA dapat dipicu oleh satu atau beberapa penyebab yaitu karena seorang individu tidak bisa keluar dari situasi eksternal yang menekannya atau tidak resisten terhadap pengaruh lingkungan yang buruk. Setelah diketahui apa penyebab, bentuk, serta efek dari masalah tersebut selanjutnya akan diketahui dimensi pelayanan apa yang akan dimunculkan untuk mengatasinya. Berdasarkan tabel di atas ada tiga variabel dalam proses munculnya masalah sosial yaitu peyebab, masalahnya sendiri dan efek. Karena satu variabel mengalami keterkaitan dengan variabel yang lain, maka penanganan harus dilakukan secara terintegrasi terhadap tiga variabel tersebut. Jika yang kita tangani adalah masalah dan efeknya, maka penanganan tersebut bersifat kuratif atau penyembuhan. Jika yang ditangani adalah penyebabnya, maka upaya tersebut adalah preventif dan pengembangan.

Jika kita mengambil pendekatan pekerjaan sosial, ada tiga level penanganan yang bisa dilakukan untuk membantu mengatasi permasalahan seperti kasus AODA ini. Level tersebut terdiri dari level individu atau mikro, level kelompok atau mezzo, dan level makro yang mencakup unsur kebijakan, keterlibatan lembaga-lembaga, organisasi, serta masyarakat secara lebih luas.

Pendekatan dengan tiga level ini sudah lama dikenal dalam praktik pekerjaan sosial sebagai bagian dari Generalist Approach. Jika contoh intervensi terhadap penggunaan obat tersebut diorientasikan agar klien harus berhenti menggunakan substance, maka permasalahan yang menyebabkan klien mengalami tekanan harus juga menjadi fokus intervensi dan dengan demikian Self coping dan kemampuan problem solving klien harus ditingkatkan.

Dalam pendekatan generalist, para pekerjaan sosial akan melakukan intervensi pada level-level berikut ini dengan kemungkinan bentuk intervensinya:

Mikro :
- Intervensi pada negative emotion / stress yang menyebabkan klien melarikan diri pada substance (cognitive restructuring) Meningkatkan self coping

- Meningkatkan kemampuan problem solving klien (life and task problems)

Mezzo :

- Self help group (ex-user participation)

- Melalui Theurapeutic group

- Meningkatkan dukungan orang terdekat seperti keluarga

- Peroblem solving bersama klien di tingkat mezzo yang menyebabkan klien lari ke substance (jika ada)

Makro :

- Mengembangkan Lembaga-lembaga pelayanan rehabilitasi narkoba di masyarakat dan menciptakan kemudahan akses (kuratif)

- Pengembangan prorgam-program pendidikan anti narkoba (preventif)

- Kebijakan untuk legal action : menghilangkan akses terhadap pengunaan substance secara tidak legal : rantai peroduksi, distribusi (prenventif-kuratif)

- Campaign : media massa (preventif)

Dalam pendekatan generalist, intervensi yang dilakukan harus holistik dan terintegrasi. Pelibatan berbagai sistem sumber pemecahan harus dimobilisasi dengan perencanaan intervensi yang baik. Jika contoh kasusnya mengenai penyembuhan orang dengan kasus AODA seperti di atas, maka pelayanan yang diberikan akan melibatkan orang-orang seseuai keahlian yang dibutuhkan.

\section{Social Entrepreneurship dan Pelayanan Sosial}

Dari semua uraian di atas dapat disimpulkan bahwa jika ada masalah sosial, maka dibutuhkan sistem pelayanan sosial. Pengadaan pelayanan sosial tersebut dimulai dengan langkah-langkah yang terdirii dari 
studi terhadap masalah itu sendiri, mengidentifikasi berbagai sistem sumber pemecahan masalah, merancang perencanaan intervensi, melakukan intervensi, terminasi, sampai evaluasi dan bila diperlukan melakukan upaya tindak lanjut.

Gambaran pendekatan generalist practice dari social work seperti diuraikan di atas menggambarkan pada kita, bahwa penanganan masalah sosial tidak cukup hanya dengan pendekatan satu dimensi dan bersifat residualkuratif, melainkan perlu ditangani secara sistematik yang melibatkan berbagai level penanganan mulai dari yang sifatnya individual sampai ke wilayah makro seperti mempengaruhi kebijakan sosial, yang juga sekaligus bisa mendukung upaya-upaya preventif dan pengembangan.

Saat ini nampaknya penanganan masalah sosial tidak akan berhasil dengan baik jika kita hanya bersikap pasif terhadap berbagai kondisi sosial yang buruk yang bisa kita lihat dan hanya mengandalkan kinerja pemerintah atau negara untuk menyelesaikannya. Partisipasi masyarakat secara luas perlu dibangun agar bisa terlibat dalam aksi-aksi sosial sehingga ada sinergi antara upaya pemerintah di satu sisi dengan kekuatan masyarakat di sisi lain. Selain itu keterlibatan masyarakat dalam memperbaiki kondisi sosial dapat sekaligus memiliki impact positif yakni munculnya kekuatan-kekuatan yang berbasis partisipasi dan tanggung jawab masyarakat sendiri untuk bisa lebih kreatif, mandiri, sekaligus kritis dan resisten terhadap faktor-faktor penyebab munculnya masalah sosial sehingga diharapkan masyarakat sebagai sebuah sistem yang terintegrasi bisa menciptakan tatanan kehidupan yang lebih baik.

Social Entrepreneurship adalah suatu bentuk semangat atau upaya setiap orang untuk bisa ikut memperbaiki kondisi sosial dan lingkungan melalui usaha-usaha pelayaan sosial yang dikelola secara mandiri. Social Entrepreneurship diartikan sebagai upaya mengembangkan serta membuka peluangpeluang baru usaha pelayanan sosial secara kreatif dan sungguh-sungguh, dengan menggerakan berbagai sumber yang dibutuhkan untuk pelayanan pertolongan, pengembangan manusia, dan pemeliharaan lingkungan.

Kewirausahaan sosial adalah sebuah gerakan untuk perubahan dengan berbahan bakar misi sosial yang kuat. Nicholls (2006) menjelaskan bahwa social entrepreneurship dengan berbagai jaringan kerjanya secara terus menerus berfokus kepada perubahan sosial yang sistemik dengan mengabaikan berbagai batasan dan norma keorganisasian maupun kelembagaan (yang mapan). Misi sosial yang ditunjukkan para social entrepreneur sangatlah kuat dan tidak pernah bisa dikompromikan. Meskipun demikian pada saat yang bersamaan mereka juga akan mengembangkan berbagai jaringan dan aliansi dengan beragam sistem sumber dimanapun berada jika itu dianggap mudah dan mendukung misi-misi mereka. Social entrepreneurship merupakan sebuah konstruk yang dinamis dan multidimensional. Ia adalah suatu bentuk organisasi hybird karena dapat menjadi sebuah bentuk campuran dari berbagai cara kerja organiasi yang berbeda dan bekerja di dalam berbagai sektor baik itu publik, private, maupun sosial, baik yang bertujuan utama profit maupun non profit.

Misi sosial dari kewirasuahaan sosial mencakup berbagai aktivitas dan gerakan sosial untuk mengatasi berbagai masalah kemanusiaan dan lingkungan dengan cara yang selintas dianggap tidak mungkin. Elkington \& Hartigan (2008), menyebut kewirausahaan sosial mencari capaian-capaian yang dianggap asing seperti mencapai keadilan sosial, menciptakan keadaan ekonomi dan lingkungan yang berkelanjutan, seringkali berupaya untuk mencapai transformasi sistem yang disfungsi, membantu memperbaiki keadaan sosioekonomi, lingkungan, atau situasi politik yang buruk.

\section{Pelaku social entrepreneurship}

Jika entrepreneurship secara umum diartikan sebagai perilaku dinamis dari orang untuk berani mengambil resiko yang terukur, 
kreatif, berorientasi pada pengembangan, sehingga tercipta peluang-peluang baru, maka siapakah yang bisa terlibat dalam usaha ini ? Jawabannya adalah setiap orang yang punya cita-cita, memiliki ide dan kemampuan menggerakan sumber-sumber yang dibutuhkan dalam pelayanan, dan memiliki kekuatan mental seperti yang tergambar dalam definisi social entrepreneurship di atas. Namun berbeda dengan entrepreneur di bidang bisnis murni dengan tujuan hanya mencari keuntungan ekonomi, wirausaha sosial karena bertujuan memberikan pelayanan perbaikan, pencegahan masalah, atau pengembangan pada kondisi sosial dan lingkungan baik pada level individu, kelompok, atau masyarakat, maka diperlukan pelibatan para profesional yang memiliki keahlian di bidang itu.

Bagaimana jika Anda misalnya bukan orang dengan latar belakang profesi pertolongan atau pengembangan manusia sementara punya cita-cita ingin bergerak di bidang social entrepreneur? Jawabannya Anda bisa berperan sebagai penyedia pelayanan sosial dengan melibatkan berbagai sumber yang dibutuhkan termasuk di dalamnya para profesional di bidang pelayanan manusia. Artinya ada peluang bagi setiap orang selama ia bisa mengorganisir serta menggerakan berbagai sumber yang dibutuhkan dalam pelayanan sosial yang bertujuan untuk pertolongan atau pengembangan manusia (human services), atau kelestarian lingkungan. Dengan demikian ada dua tipe wirausaha sosial yaitu mereka yang tidak memiliki latar belakang profesi pelayanan kemanusiaan tetapi mampu mengelola dan menggerakan berbagai sumber yang dibutuhkan pelayanan termasuk sumber daya manusianya dan kedua para profesional di bidang pelayanan kemanusiaan yang sekaligus juga berperan sebagai social entrepreneur.

Adapun sumberdaya manusia yang terlibat memberikan pelayanan langsung (direct services) pada masyarakat dalam lembaga pelayanan sosial memerlukan syarat-syarat kompentensi yang beragam sesuai kebutuhan. Untuk di Indonesia, ada yang melibatkan profesioanal dengan latar belakang pendidikan formal strata satu atau master misalnya social worker, atau psikolog serta ada pula yang melibatkan paraprofesional atau non profesional yang berarti mereka bekerja di lembaga-lembaga pelayanan sosial tanpa latar belakang pendidikan strata, melainkan dengan training-training atau kursus-kursus. Paraprofesional ini biasa bekerja sebagai volunteer atau asisten profesional dalam lembaga-lembaga pelayanan tersebut. Masingmasing orang yang terlibat tentunya memiliki perbedaan fokus dan kontribusi sesuai kompetensinya. Masalah sosial memiliki dimensi serta aspek yang luas dan beragam. Pada praktiknya akan membutuhkan banyak profesi dengan fungsionalitas yang terintegrasi sesuai kebutuhan pelayanan.

\section{Daftar Pustaka}

DuBois, Brenda \& Karla Krogsru Miley, 2005. Social Work an Empowering Profession. Pearson Education, Inc.

Elkington, John \& Pamela Hartigan, 2008. The Power of Unreasonable People: How Social Entrepreneurs Create Markets That Change The World. Harvard Business Press.

Friedlander, 1987. Introduction to Social Work. Prentice Hall

Grafton Hull Jr \& Krist Ashman, 1993. Understanding Generalist Practice. Englewood New Jersey : Prentice Hall.

Nicholls, Alex, 2006. Social Entrepreneurship : New Models of Sustainable Social Change. Oxford University Press.

Parillo N. Vincent, 2002. Contemporary Social Problem. Allyn \& Bacon.

Payne, Malcolm, 1997. Modern Social Work Theory. Mc Millan Press, Ltd.

Raharjo, ST. 2015. "Pekerjaan Sosial Generalis, Suatu Pengantar Bekerja Bersama Organisasi dan Komunitas", Edisi Revisi Buku, Unpad Press, 


\begin{tabular}{|c|c|c|c|c|}
\hline $\begin{array}{c}\text { 118SHARE: SOCIAL WORK } \\
\text { JURNAL }\end{array}$ & VOLUME: 7 & NOMOR: 1 & HALAMAN: 1 - 129 & $\begin{array}{l}\text { ISSN:2339 -0042 }(p) \\
\text { ISSN: 2528-1577 }(e)\end{array}$ \\
\hline
\end{tabular}

Raharjo, ST. 2015. "Dasar Pengetahuan Pekerjaan Sosial”, Buku, Unpad Press

Raharjo, ST., Taftazani, BM., Apsari, NC., Santoso, MB. 2016. "PANDUAN PRAKTIKUM MIKRO (Konseling dan Pengembangan Diri)". Buku . Unpad Press.

Raharjo, ST. 2015. "Assessment dan Wawancara dalam Prakti Pekerjaan Sosial dan Kesejahteraan Sosial", Edisi Revisi Buku, Unpad Press

Soetomo, 1995. Masalah Sosial dan Pembangunan. Jakarta : Pustaka Jaya. 
